Iranian Quarterly Journal of Breast Disease 2018; 11(3):32.

\title{
The Effect of Endurance Training on Tumor Tissue Levels of Caspase- 3 and Caspase-9 in Mice with Breast Cancer
}

Kazemi A: Dept of Sport Sciences, Faculty of humanity and literature, Vali E ASR University of Rafsanjan, Rafsanjan, Iran

Mirzazadeh E: Exercise Physiology Dept, Faculty of humanity and literature, Islamic Azad University, Kerman, Iran

Corresponding Author: Abdolreza Kazemi, a.kazemi@vru.ac.ir

\begin{abstract}
Introduction: Today, cancer is the second leading cause of death, and breast cancer is the most common cancer, among women. The levels of apoptotic factors, such as caspases, decrease in tumor, leading to tumor growth. The present study investigated the effect of aerobic exercise on the regulation of caspase- 3 and -9 in breast cancer.
\end{abstract}

Methods: After familiarization, $20 \mathrm{BALB} / \mathrm{c}$ mice received transplants of estrogen receptor-positive MC4-L2 tumor cell line to develop cancer. The animals were then randomized into two groups: control $(\mathrm{n}=10)$ and exercise $(\mathrm{n}=10)$. The exercise group performed incremental endurance training (at $18-22 \mathrm{~m} / \mathrm{s}$, equivalent to $55 \%$ to $70 \%$ of aerobic capacity in mice) for 6 weeks, 5 days per week, while the control group did not exercise. Tumor volume was measured in on a weekly basis with a digital caliper. At the end of the study, mice were sacrificed, and tumor tissues were removed and frozen in liquid nitrogen and stored at $-70^{\circ} \mathrm{C}$. Tissue levels of caspase- 3 and caspase- 9 were measured using ELISA kits (catalogue number: SEA626Mu and E03C0551, respectively).

Results: The expression of caspase-3 $(p=0.001)$ and caspase- $9(p=0.013)$, and the ratio of heart weight to body weight $(p=0.001)$ were significantly greater in the exercise group than in controls. On the other hand, the exercise group had a significantly lower rate of tumor growth $(p=0.001)$ and tumor weight $(\mathrm{p}=0.001)$ compared with the controls.

Conclusion: Aerobic exercise can increase the expression of caspase- 3 and caspase- 9 and reduce tumor growth rate and tumor weight in breast cancer. Therefore, it can be claimed that exercise training can reduce tumor volume, and thus improve the condition of the mice with cancer, by increasing the levels of apoptotic factors.

Keywords: Breast Cancer, Endurance Training, Caspase-3, Caspase-9

This study was approved by the Animal Ethics Committee of Sport Sciences Research Institute in 2016. The registration number was IR.SSRI.REC.1395.129. 


\title{
تأثير يك دوره تمرين استقامتى بر ميزان بروتئين كاسياز ب و 9 بافت تومور موشهاى مبتلا به سر طان يستان
}

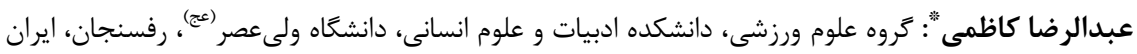

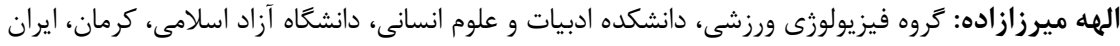

\section{جكيده}

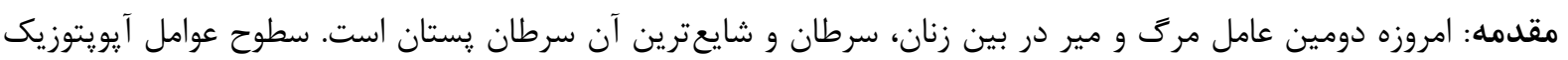

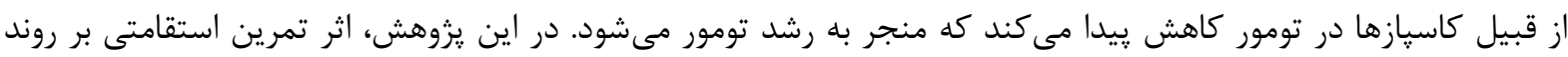

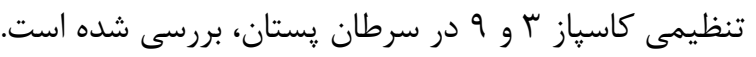
روش بررسى: مطالعه حاضر از نوع تجربى است. يس از آشناسازى حيوان با محيط، تومور سرطان يستان وابسته به كيرنده

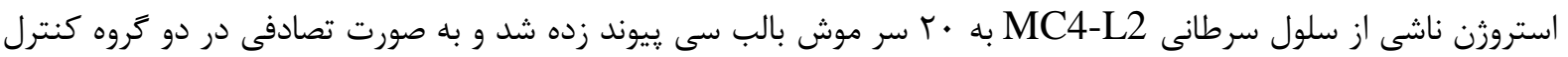

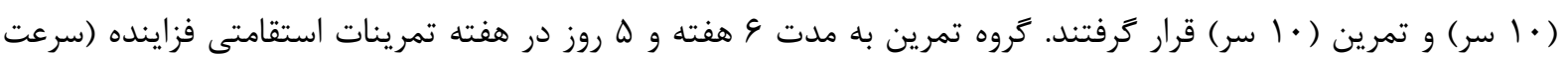

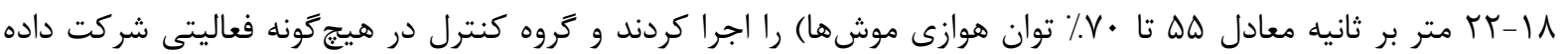

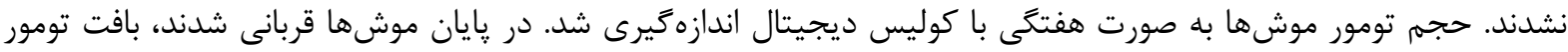

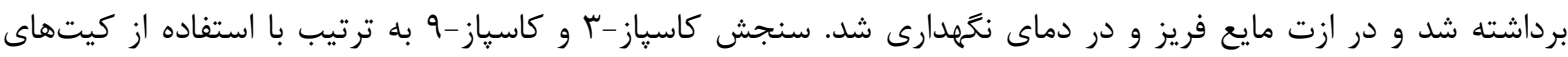

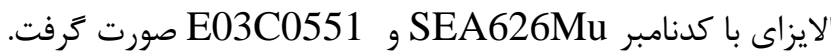

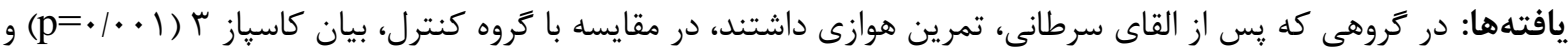

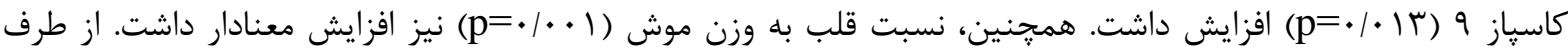

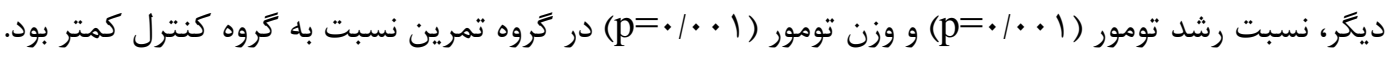

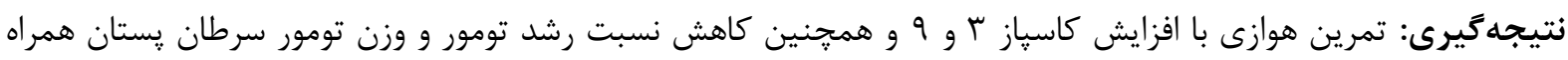

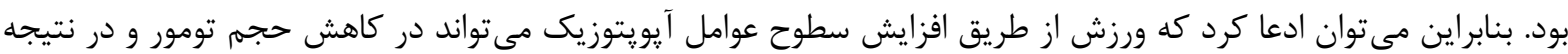
بهبود وضعيت موشهاى مبتلا به سرطان سهيم باشد. وازههاى كليدى: سرطان بستان، تمرين استقامتى، كاسياز ب، كاسياز 9 
مشخص شدهاند. نخست، مسير وابسته به ميتوكندرى، كه

به نشانهاى خارج سلولى و عوامل داخلى از قبيل آسيب

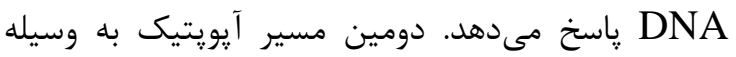

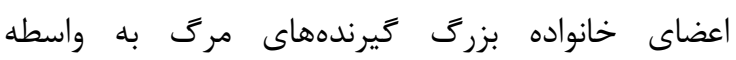
فعالسازى كاسياز-1 تحريك مىشود (V). اكثر داروهاى ضد سرطان، آيويتوز را از مسير ميتوكندريايى تحريك آنسي

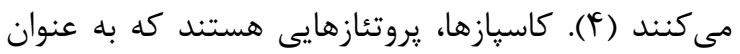

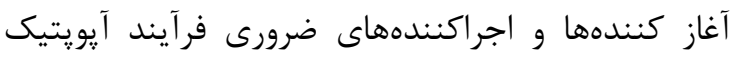
ايفاى نقش مى كنند. به صورت كلاسيك، آبشار كاسيازى

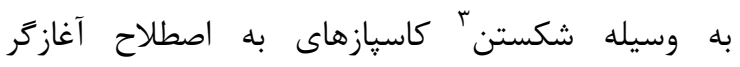
(كاسياز-ז، كاسياز-1)، كاسياز-9 و و كاسياز • (1) به احتمال

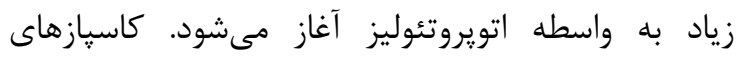

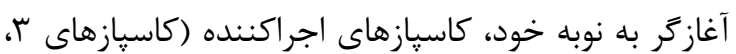

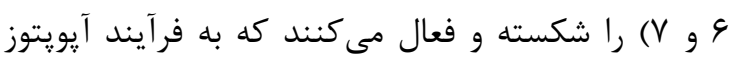

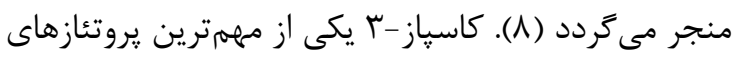

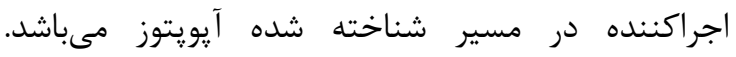

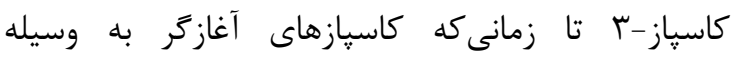

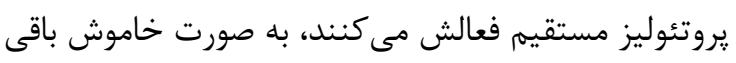

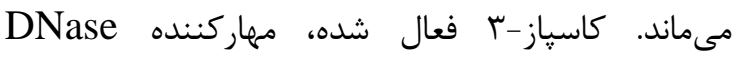

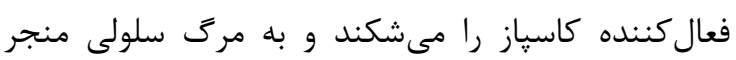

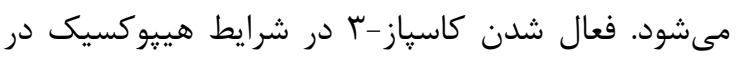

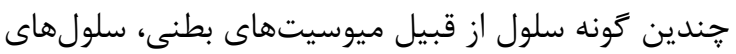

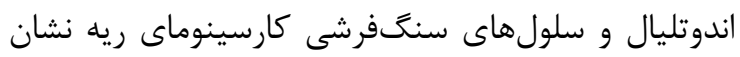

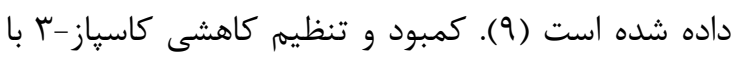

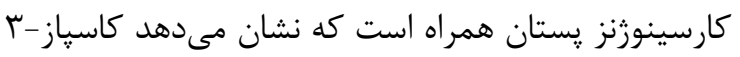

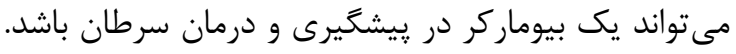

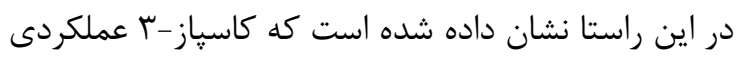
براى راديوترايى و شيمىدرمانى مؤثر ضرورى است (• (1).

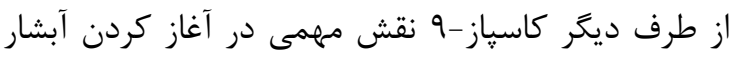

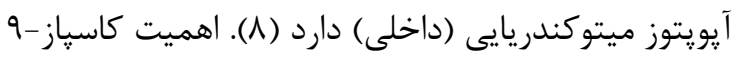

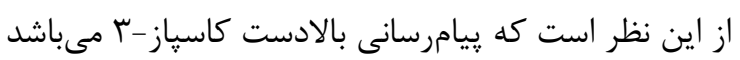

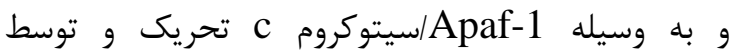
فرآورده انكوزن Akt مهار مىشود (1) (1). در راستاى

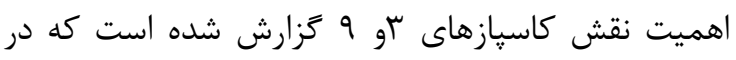

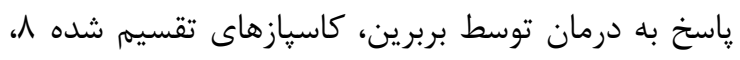

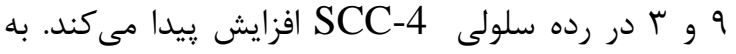

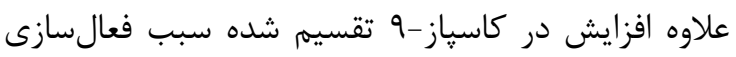

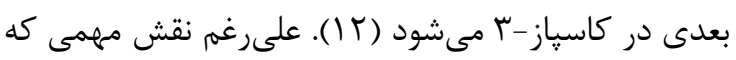

${ }^{3}$ Cleavage
سرطان يكى از مشكلات اصلى سلامت در سراسر جهان و

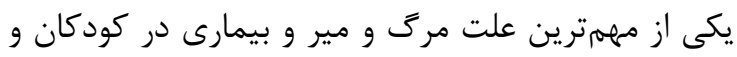

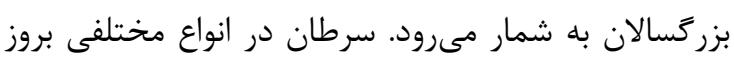

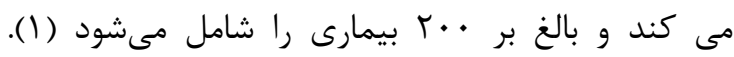

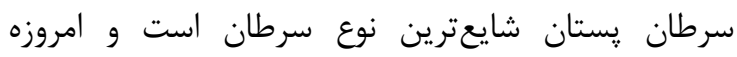

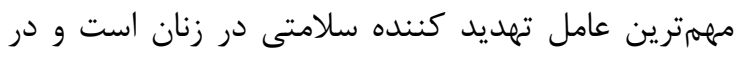

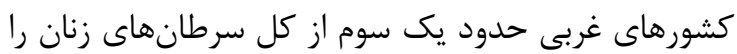

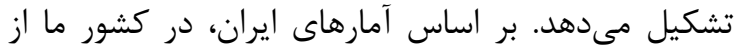

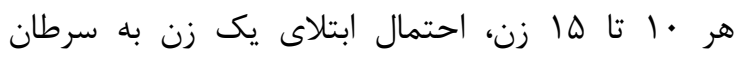

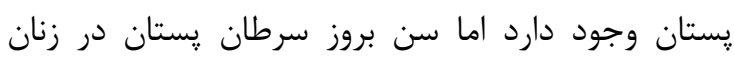

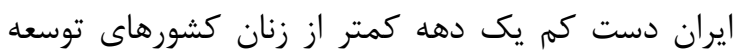

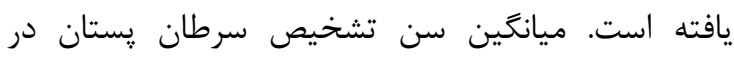

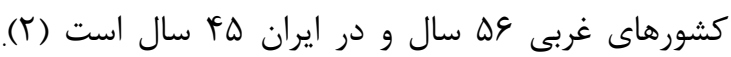

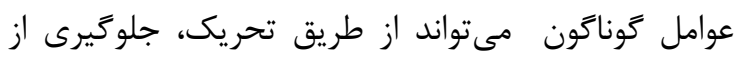

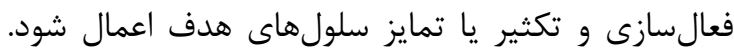

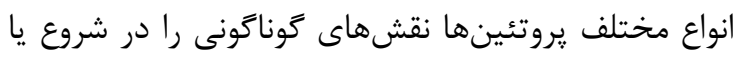
تكثير سرطان ايفا مى كنند و مىتوانند از يك طرف زئن زمينه را براى بروز و حتى تكثير و متاستاز سرطان فراهم بكنند و از طرف ديكر از طريق آثار ضد التهابى و ضد وند تومورى، از ريشرفت و توسعه سرطان جلو گيرى كنند (rا). مركى سلولى از دو طريق ايجاد مىشود: نكروز و آيويتوز

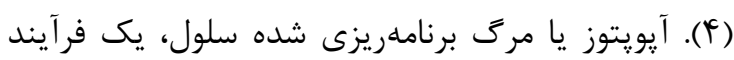

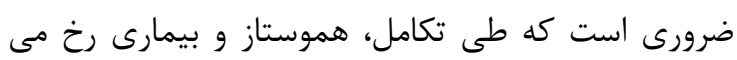
دهد. بر خلاف نكروز يا ساير اشكال مرك سلولى كه از هم

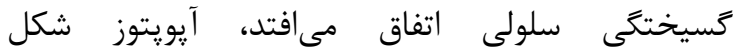

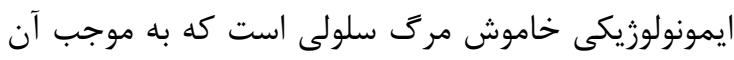

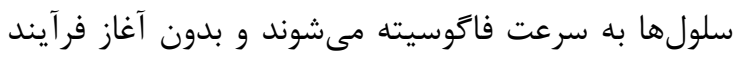

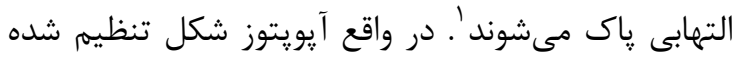

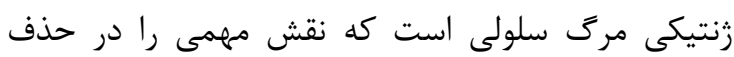

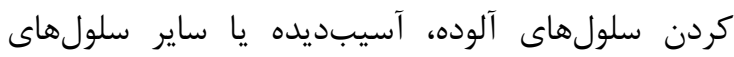

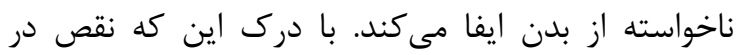

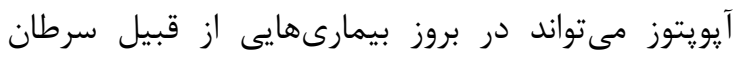

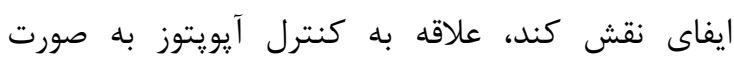

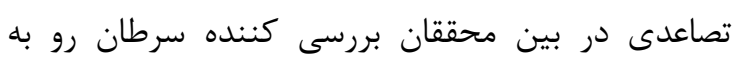

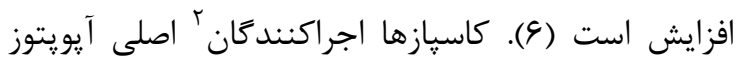
هستند. تا به امروز دو مسير يِامرسانى عمده آيويتوز

\footnotetext{
${ }^{1}$ Cleared

${ }^{2}$ Executioners
} 
״يدايش تومور سرطانى، موشها به طور تصادفى به دوكروه

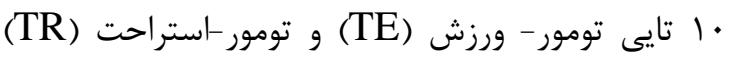

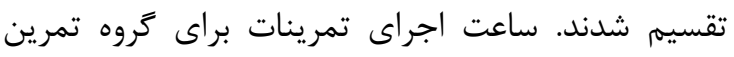

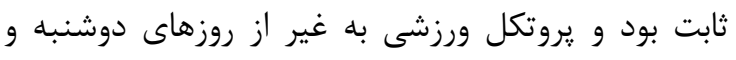

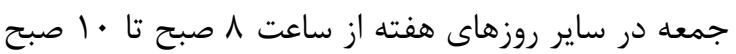

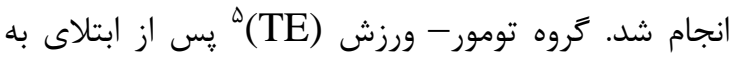

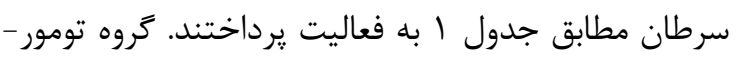

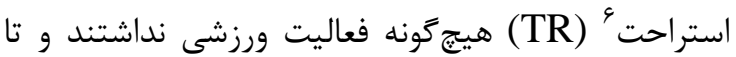
پايان يروتكل به زندگى طبيعى خود ادامه دادند. در هر

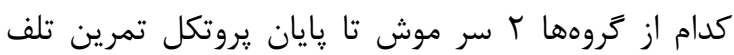
شد كه در آنالايز نيز حذف شدند. كليه اصول اخلاقى كار با حيوانات آزمايشگاهى در انجام يزوهش حاضر رعايت شد و يزوهش حاضر داراى كد إنا

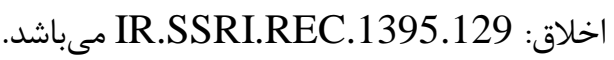

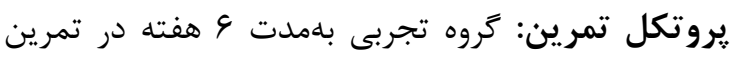
استقامتى فزاينده شركت داده شدند. تمرينات در هفته اول تمرين با سرعت \| متر در دقيقه شروع و در نهايت

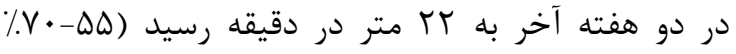

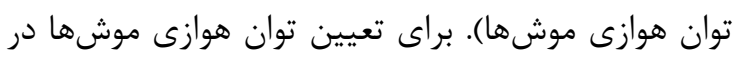

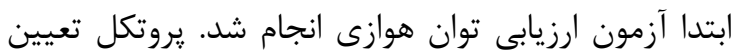

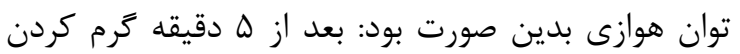

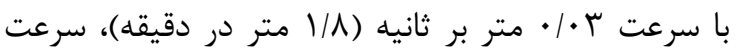
نواركردان هر ب دقيقه يك بار افزايش يافت، حداكثر سرعت بيشينه زمانى است كه موشها نتوانند با يك إنى

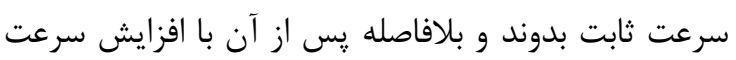

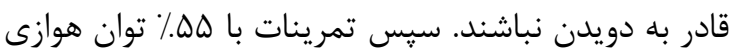

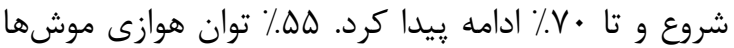

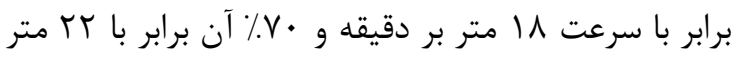
در دقيقه بود (جدول ()). نحوه ايجاد تومور: تومورى كه در يزوهش حاضر مورد بررسى قرار كرفت از نوع آدنوكارسينوماى موشى بود كه به وسيله تزريق سلولهاى سرطانى به صورت زير جلدى در موشها ايجاد شد. در ابتدا سلولهاى مورد نظر در

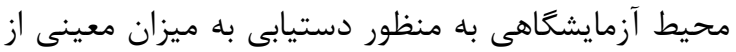

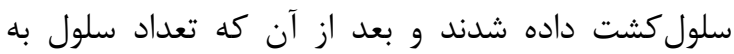

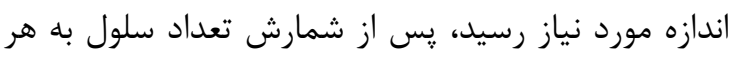
موش به ميزان يك ميليون سلول تزريق شد.

${ }^{5}$ Tumor-Exercise 6 Tumor-Rest
كاسيازهاى 9 و ب در آيويتوز سلولى دارند، تا كنون

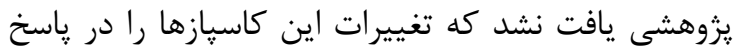

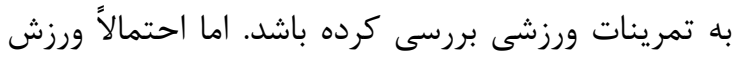

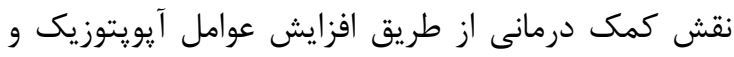

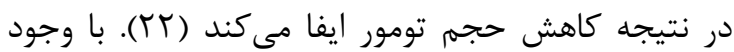
اين، برخى اثر مكملها و داروهاى مختلف را بر تغييرات

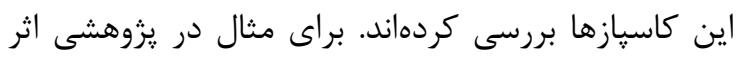

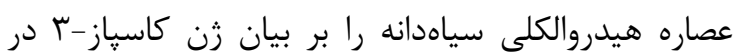
رده سلولى MCF7 سرطان يستان بررسى كردند كه

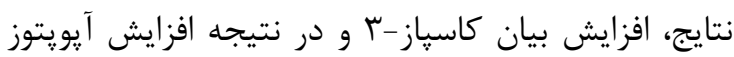

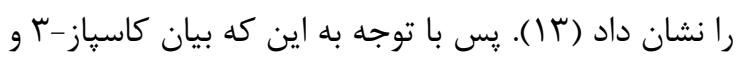

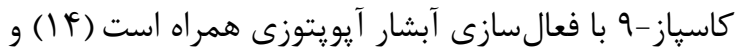

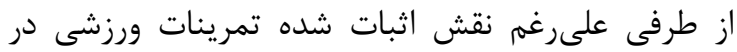

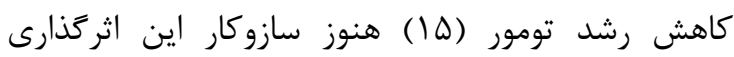
مشخص نشده است، هدف از يزوهش حاضر بررسى اثر هن

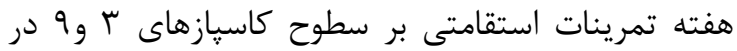
بافت تومور و عضله موشهاى ماده مبتلا به سرطان بستان

\section{مواد و روشها}

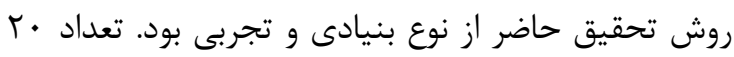
سر موش بالب سى ماده (ل تا 9 هفتهايى، ميانكَين توده

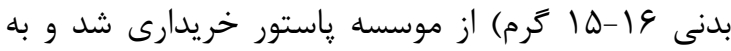
حيوان خانه منتقل شد. در هر قفس بَ الى أل موش قرار

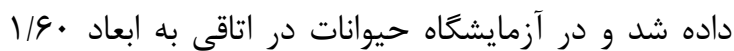

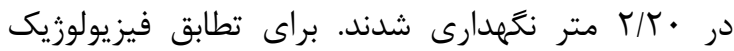
موشها، دوره T) ساعته تاريكى روشنايى (شروع روشنايى

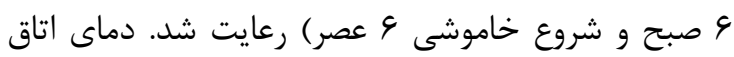

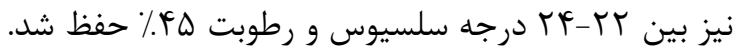

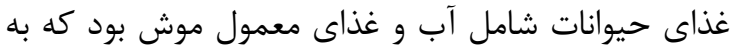

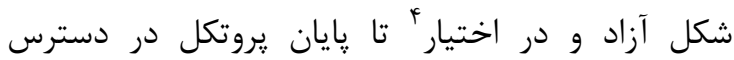
موشها قرار كَرفت. قفسهايى كه براى نكَّدارى موشها

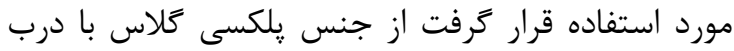

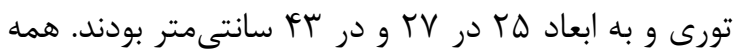
موشها به مدت ا هفته با شرايط زندكى در حيوان خانه و

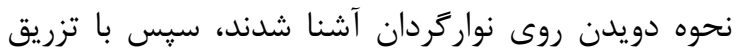

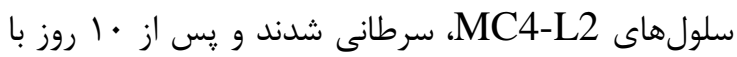

${ }^{4}$ ad Libitum 
جدول ا: يروتكل تمرين هوازى براى كروه تمرين

\begin{tabular}{|c|c|c|c|}
\hline تكرار (روز در هفته) & زمان كل تمرين (دقيقه) & سرعت تمرين (متر بردقيقه) & دوره تمرين \\
\hline$\Delta$ & $r$. & $\mid r-1$ & مرحله آشنا سازى \\
\hline$\Delta$ & 4. & 11 & دو هفتهى اول \\
\hline$\Delta$ & $\checkmark$. & $r \cdot$ & دو هفتهى دوم \\
\hline$\Delta$ & $\checkmark \Delta$ & tr & دو هفتهى سوم \\
\hline
\end{tabular}

يروتكل به گونهاى بود كه وزن گروه تمرين تقريبا ثابت باقى ماند و وزن گروه كنترل افزايش يافت.

وزن تومور و وزن قلب و نسبت وزن قلب به وزن بدن: در جدول r مقادير وزن تومور و وزن قلب موشها در هفته آخر يس از كشتار ارايه شده است. وزن قلب در گروه تمرين 11|•

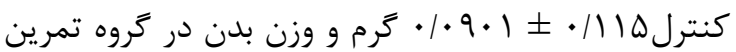
| • •

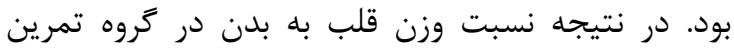

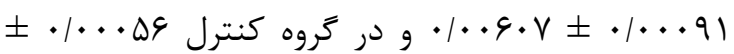

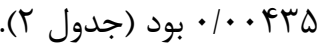

در جدول ץ مقادير غلظت كاسياز-ץ و -9 بافت تومور موشها در يايان يروتكل تمرين در دو گروه يزوهش ارايه

شده است، تغييرات هر دو طبق جدول f أمعنى دار بود. نسبت رشد تومور: در شكل r روند رشد تومور در دو گروه

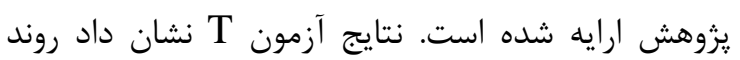
رشد تومور (نسبت هفته ششم به هفته اول) در كروه كنترل شيب بالاترى نسبت به گروه تمرين دارد

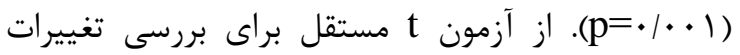

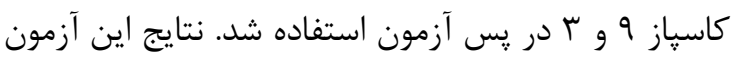
در جدول ₹ ارايه شده است. با توجه به ارزش P به دست آمده، و هفته تمرين هوازى بر سطوح كاسياز بـ و 9 بافت

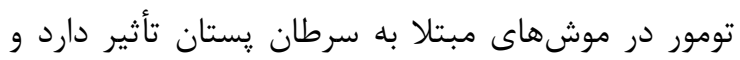

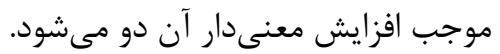
نتايج يزوهش حاضر نشان داد كه به دنبال \& ه هفته تمرينات استقامتى، مقادير كاسياز-ب و 9 در بافت تومور و و

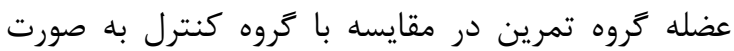

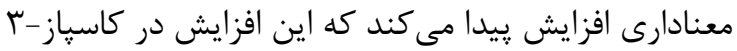
و 9 با كاهش معنادار حجم تومور در گروه تمرين كرده،

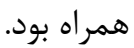

قبل از تزريق سلولهاى سرطانى، موشها به وسيله تزريق تركيب زايلازين و كتامين به صورت زير جلدى بىهوش لهون شدند و سيس سلولهاى سرطانى به صورت زير جلدى به به به موشها تزريق گرديد. اندازهيرى حجم تومور: حجم تومور در ب بعد اندازهيرى شد. بزرگترين بعد تومور به عنوان طول (L)

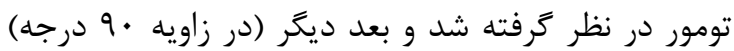
به عنوان عرض (W) در نظر زرفته شد. به دنبال ييوند و ييدايش تومور، هر دو روز يك بار طول و عرض تومور

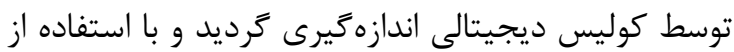
فرمول محاسباتى حجم تومور حجم تومور در هر تهار گروه اندازهگيرى شدم. نسبت وزن قلب به وزن موشها: از نسبت وزن قلب به وزن موش به منظور بررسى اثربخشى فيزيولوزيك تمرين

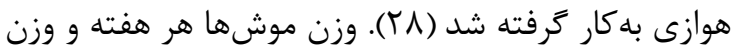
قلب موشها با استفاده از ترازوى ديجيتال بلافاصله يس از بره كشتن موشها، سنجيده شد. روش آمارى: تمام يافتهها با ميانخين و انحراف استاندارد كزارش شد. ابتدا با استفاده از آمار توصيفى به تشريح و

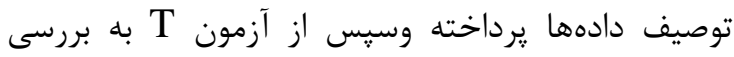

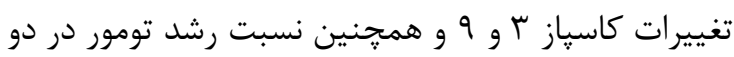
كروه كنترل و تمرين استفاده شد. براى تعيين نحوهى توزيع دادهها از آزمون كولموكروف اسميرنوف استفاده شد. همجنين براى بررسى آزمون فرضيهها و تصميمى

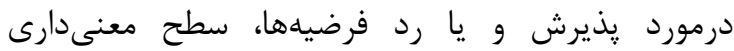

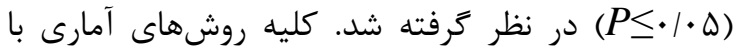
استفاده از نرمافزار SPSS نسخه 9 SPS 1 انجام كرفت

\section{كافتهها}

وزن موشها: در شكل 1 وزن موشهاى دو گروه به تفكيك در هر هفته ارايه شده است. در شروع مطالعه وزن مون موشها در دو گروه تقريباً برابر بود. تغييرات وزن تا پايان 


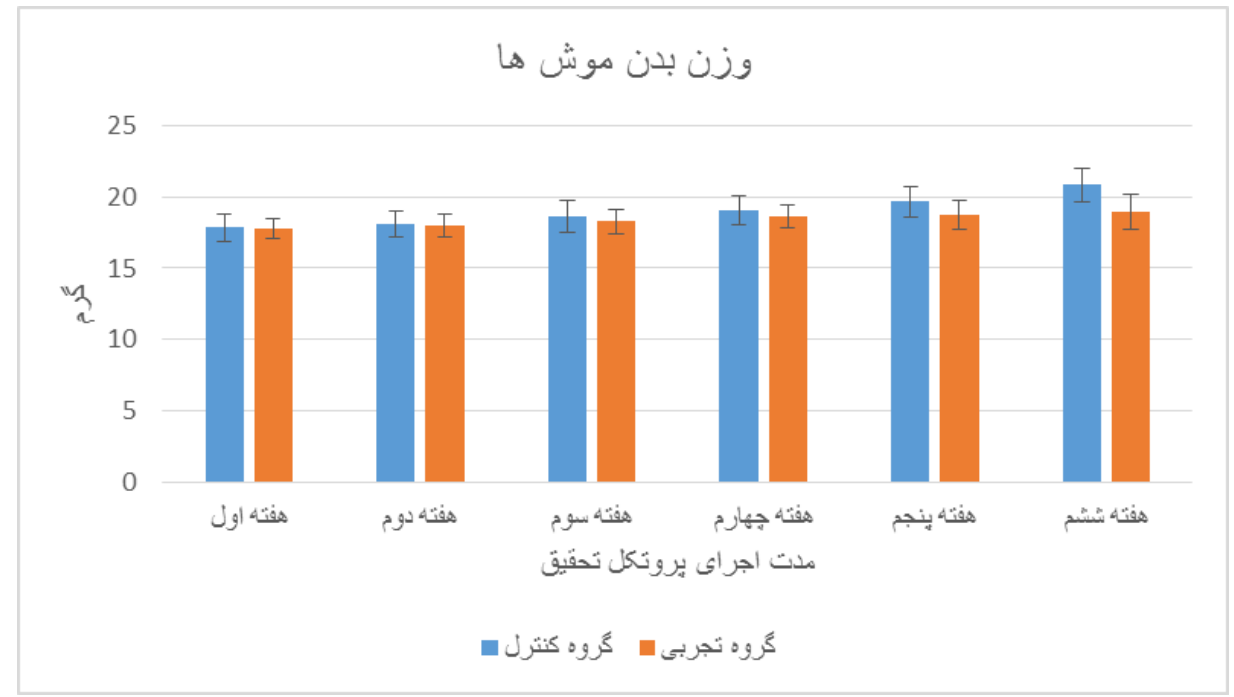

شكل ا: مقايسه وزن موشهاى دو گروه طى اجراى يزوهش

جدول r: وزن قلب، وزن تومور و نسبت وزن قلب به وزن بدن موشها به تفكيك دو كروه

جدول r: مقادير غلظت كاسياز -r و -9 در گروههاى مختلف يزوهش (نانوَرم بر ميلىليتر )

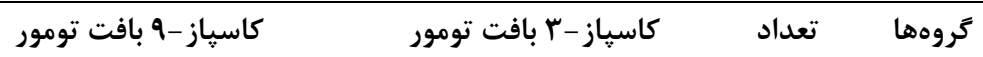

(ميانگين و انحراف استاندارد) (ميانگين و انحر اف استاندارد) )

\begin{tabular}{|c|c|c|c|}
\hline$\Lambda / I V \pm \Gamma / \mu$ & $V(\Lambda+1 / f \mid$ & $\wedge$ & كنترل \\
\hline $11 / V \Delta \pm 1 / r T$ & $\mid F / F F \pm 1 / \cdot \Lambda$ & $\wedge$ & تمرين \\
\hline
\end{tabular}

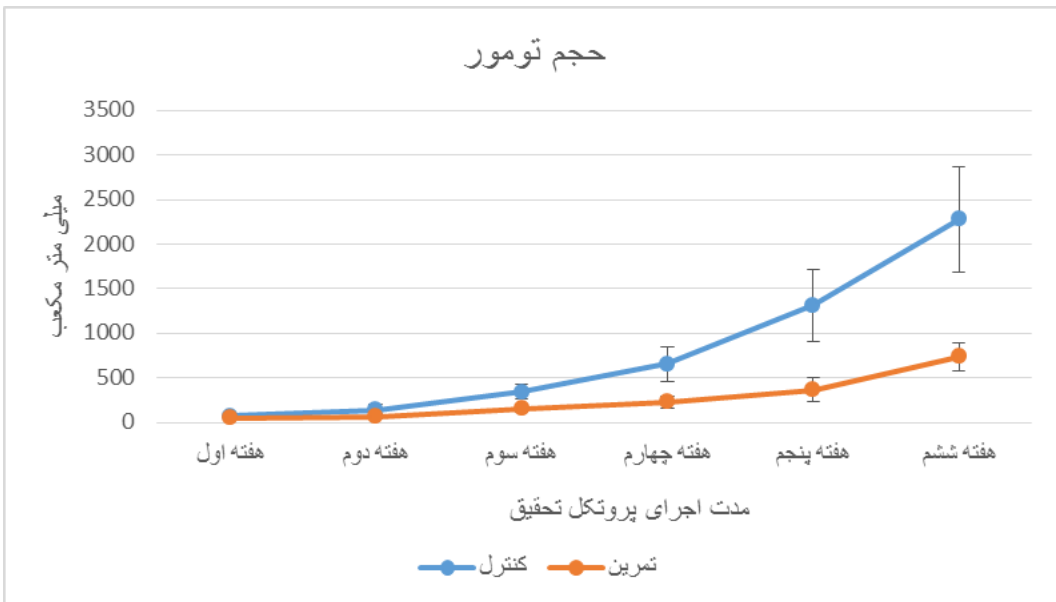

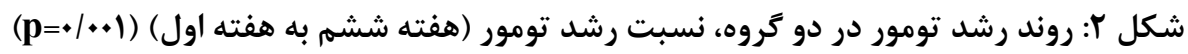




\begin{tabular}{|c|c|c|c|}
\hline ارزش P آزمون & t & آزمون لون & \\
\hline & & ارزش p آزمون لون & \\
\hline$\cdot / \cdot \cdot *$ & $1 \cdot / 0$ & $\cdot|V 9|$ & كاسياز-r \\
\hline$\cdot / \cdot 1 \% *$ & T/AF & . $1<99$ & كاسياز-9 \\
\hline
\end{tabular}

در يزوهشى ديخر بر روى نمونههاى تومور پيستان انسان،

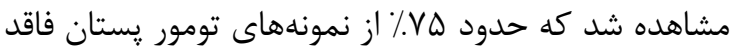

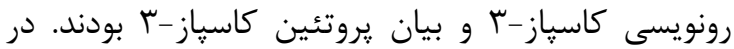

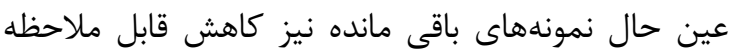
بيان كاسياز-ب را نشان دادند. جالب اين كه كاهش مشابه در بيان كاسياز-r در بافتهاى مجاور بافت تومور افراد مبتلا به سرطان يستان كه به لحاظ ريختشناسى طبيعى

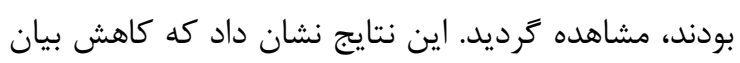

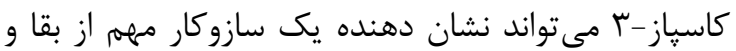
مقاومت در برابر شيمىدرمانى در سلولهاى سرطانى

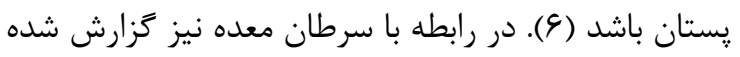

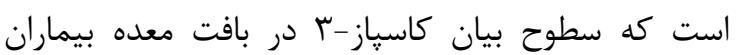

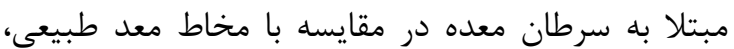
קايينتر است (·) (Y). نتايج يزوهش حاضر نشان داد، 9 هفته تمرين هوازى بر بر بانب

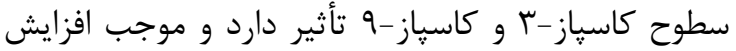
معنى دار آن مىشود و ميزان غلظت كاسياز-بّ و كاسياز-و

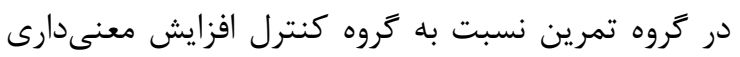
دارد. يزوهشى كه اثر تمرين ورزشى بر سطوح كاسيازهاى نداى در بافت تومور و سرم موشهاى مبتلا به سرطان را بررسى داري كند يافت نشد. با اين وجود برخى مطالعات كه اثر تمرين

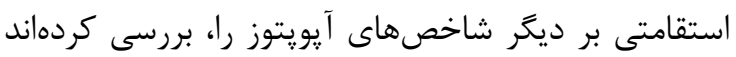

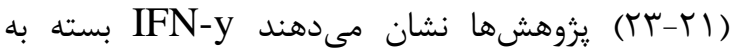

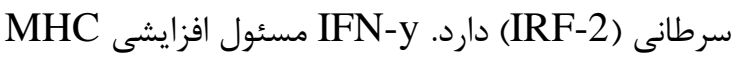

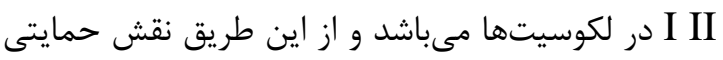
در سرطان دارد. IFN-y با تنظيم افزايشى برخى از إنى

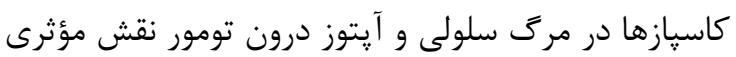

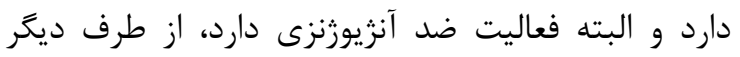
IFN-y تحقيق همسو با تحقيق حاضر مىباشد. فاكتور IFN-y در

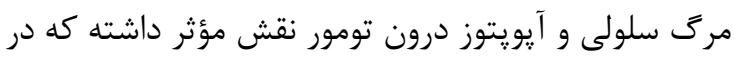

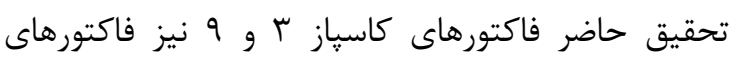
مؤثر در فرايند آيويتوز مىباشند.
كزارش شده است كه كاسياز-r براى آيويتوز ناشى از

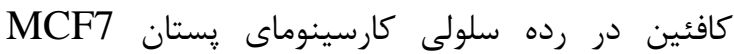
ضرورى است و فرض بر اين است كه يكى از دلايل فنوتيٍ مقاوم در برابر راديوترايى اين سلولها، تخليه

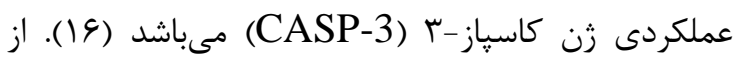

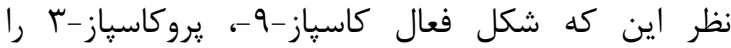

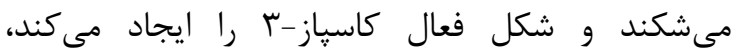

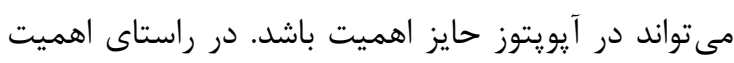
اين دو كاسياز در آيويتوز سلولهاى سرطانى مشاهد آنده شده

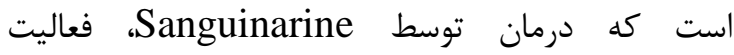

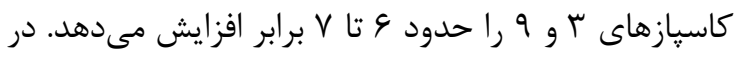
واقع اين كاسيازها در سلولهاى بعد از درمان با Sanguinarine فعال مىشوند كه نشان مىدهد Sanguinarine، آيويتوز را به وسيله دئه مسير وابسته به كاسياز در اين رده سلولى تحريك مى كند (IV). همجنين קُندين مطالعه نشان دادهاند كه فعالسازى

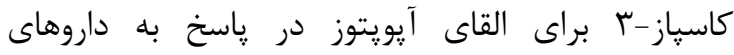

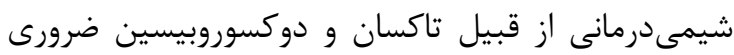
است. از آن جا كه كاسياز-ب تنظيم كننده كليدى آيويتوز است و با ميزان آيويتوز در سرطان پستان مرتبط است،

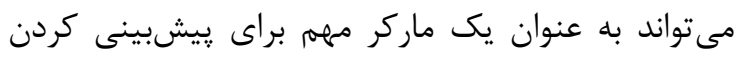

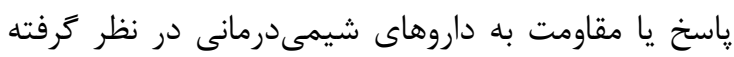
شود (1)). از طرف ديكر، افشار جعفرى و همكاران

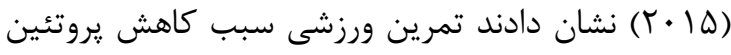

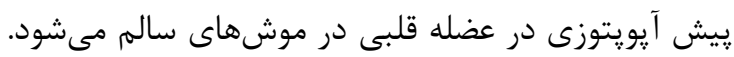
تغيير در نسبت Bax/Bcl-2 براى القاى آيويتوز ضرورى دئيق

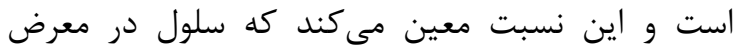

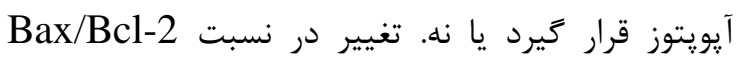
باعث رهايش سيتوكروم C از ميتوكندرى به درون

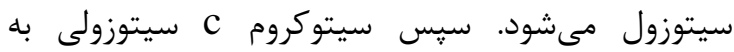

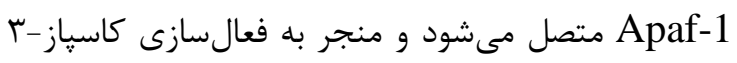

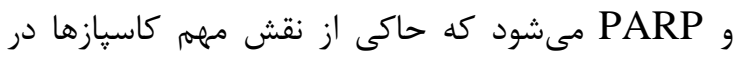

آيويتوز است (19). 
آيويتوز بوده و موجب فعال شدن كاسياز-ب يعنى كاسياز اجر ايى پايين دست مىشود كه فاكتورهاى مؤثر در فرايند

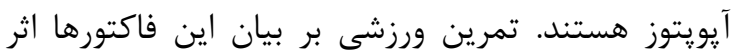

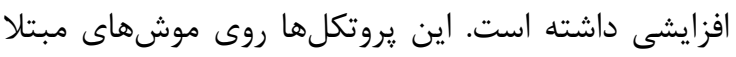
به سرطان انجام شد (TY) - (T). צ هفته تمرين هوازى بر نسبت رشد تومور در موشهاى الجاى

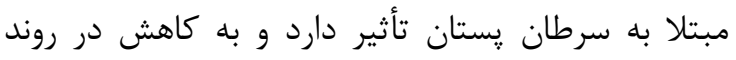
رشد حجم تومور در كروه تمرين منجر شد. روند رشد بد داند تومور در گروه كنترل شيب بالاترى نسبت به كروه تمرين

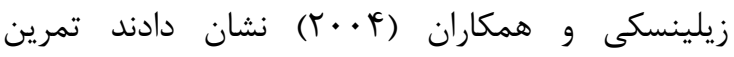
استقامتى در موشهاى بالب سى موجب كاهش رشد

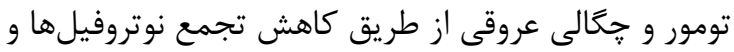

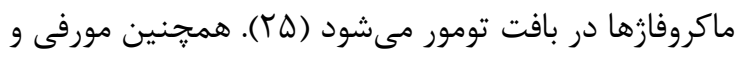

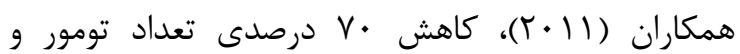

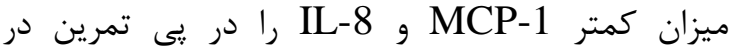

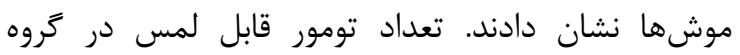

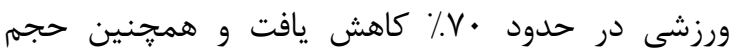

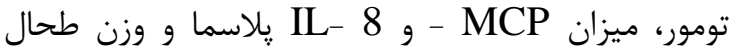

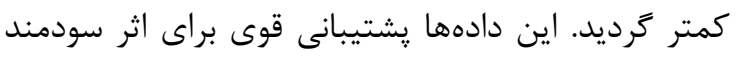
ورزش در كاهش تومور و اثر ضد التهابى در موش مبتلابه سرطان يستان را نشان مى دهند (צا). علاوه بر اين، جونز

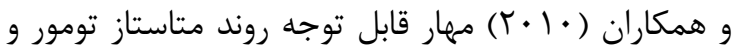

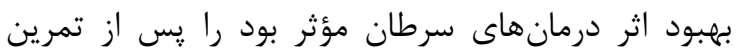

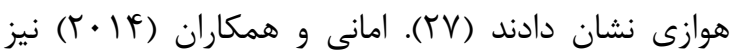

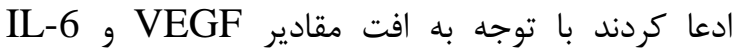

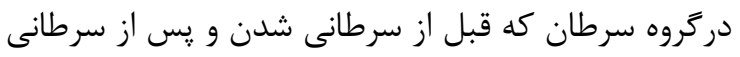

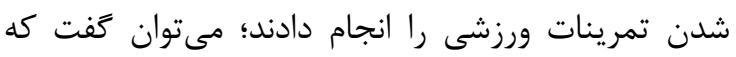

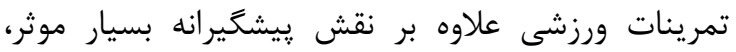
داراى نقش كمك درمانى در تومورهاى وابسته به كيرنده

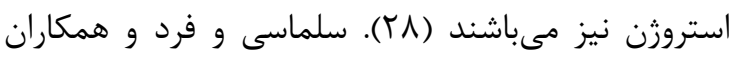

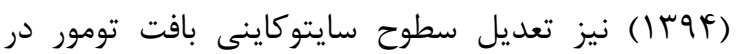
نتيجه تمرينات استقامتى را مطرح كردند. به طورىكه افزايش سايتوكاينهاى ضد ركزايى مانند مؤثر در كاهش حجم تومور گروه ورزشى است. لذا با توجه به اين اثرات مثبت، مىتوان از تمرينات ورزشى به عنوان

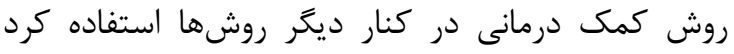

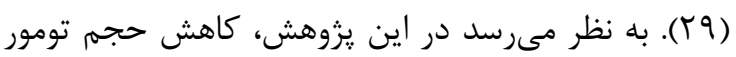
مشاهده شده در موشهاى بالب سى، به دنبال تمرينات

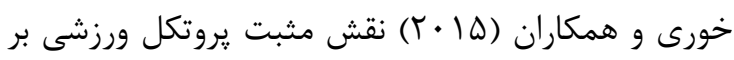
وزن تومور يستان در موش را از طريق مهار مسير اساسى

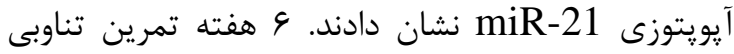

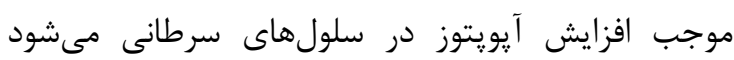

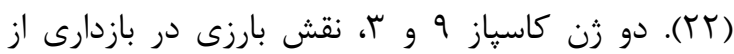

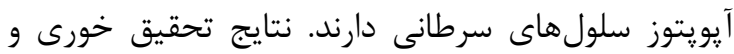

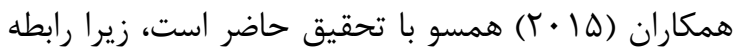

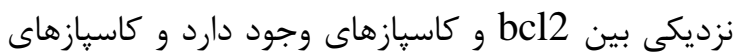
افكتورهاى نهايى در آيويتوز مىباشند.

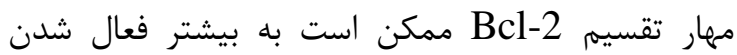

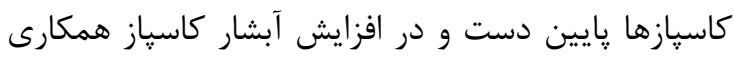

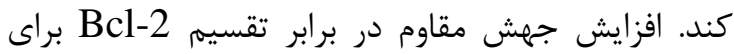

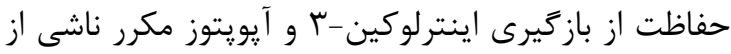

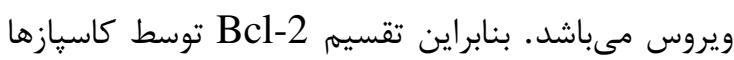
از مرى سلولى اجتناب نايذير ممكن است، مراقبت كند (T) يك تنظيم كننده برنامه فعالسازى كاسياز

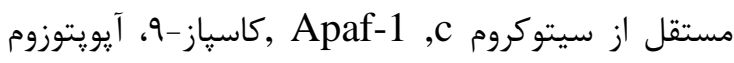

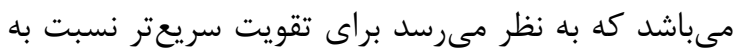

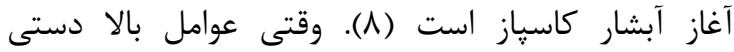

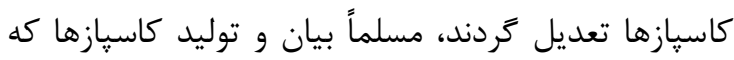

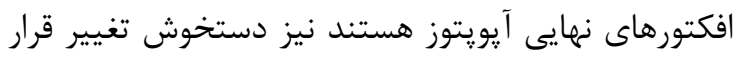

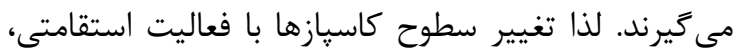
يذيرفتنى مىباشد. Mir - توجه به اثر افزايشى تمرين ورزشى هوازى بر بياند

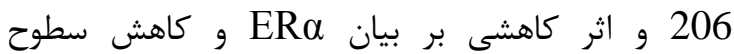

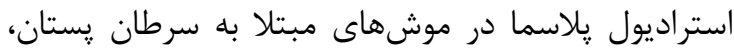
تمرين هوازى، اين حلقه تنظيمى را به سمت كاهش تكثير

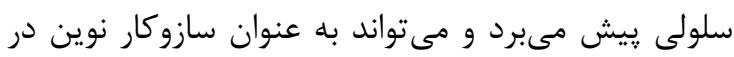

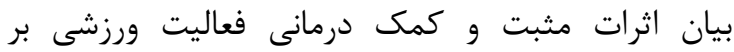
سرطان يستان در نظر گرفته شود (YY). اين تحقيقات همسو با تحقيق حاضر بود، مطالعه روى فاكتور انجام كرفته كه تمرين ورزشى بر بيان اين فاكتور اثر بران

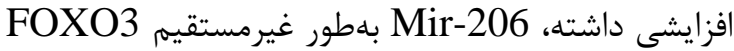

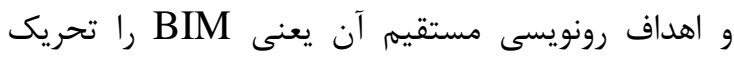

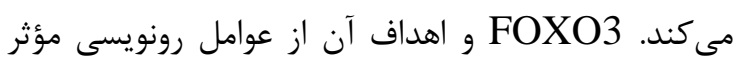
در فرايند آيويتوز هستند و بنابراين يتانسيل Mir-206 در آيويتوز سلول تومور نقش دارد.كه در تحقيق حاضر نيز كه مطالعه بر روى فاكتورهاى كاسياز r و و 9 مى كىاشد كاسياز- 9 يك كاسياز آغازگر در مسير ميتوكندريايى 
يكى از نتايج جالب ديگر در يزوهش حاضر معنى دارى

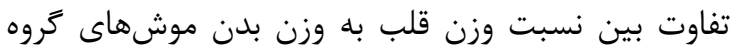
تمرين در مقايسه با كروه كنترل بود. اين شاخص نشان دهنده كارايى تمرين است. در واقع تمرين استقامتى با داني شدت متوسط توانسته اثرات خود رات بر ساخت إنتارهاى تمرينيذير مانند قلب نشان دهد و مىتوان ادعا كرد تمرين استقامتى با شدت متوسط در موشهاى حامل تومور مؤثر بوده است و تغييرات ايجاد شده در در سطوح

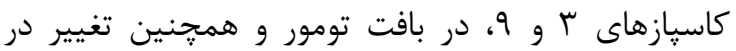
وزن بدن قابل استناد به تمرين استقامتى مىباشند. يكى إسى

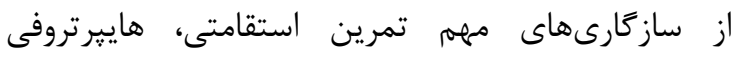
برونكراى قلب مىباشد. كاشكسى موجب كاهش تودها عضلانى و توده جربى و همين طور كاهش توده قلب

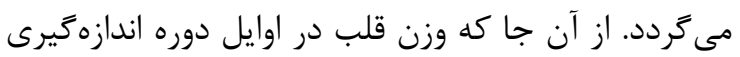

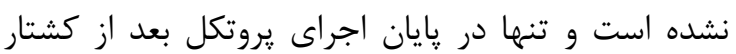
اندازهزيرى شده است، مىتوان بيان داشت كه يا تمرين

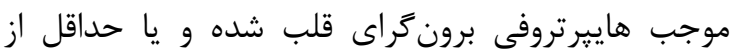

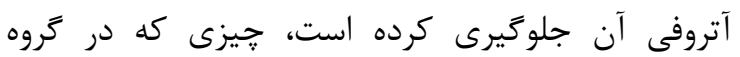
كنترل مخالف آن رخ داده است. در كل، نسبت وزن قلب به وزن بدن موش شاخص مناسب كارايى تمرين و نشان دهنده جلوَيرى از اثرات كاشكسى سرطان باخ موشي تمرينات

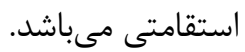

\section{نتيجه " نيرى}

به نظر مىرسد تمرينات استقامتى از طريق تعديل وضعيتى آيويتوزى (تعديل بيان زن كاسياز r و و 9) در كاهش رشد تومور درگير باشد. لذا انجام تمرينات استقامتى با شدت متوسط (با توجه به تغييرات معنىدار

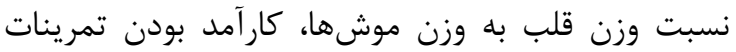

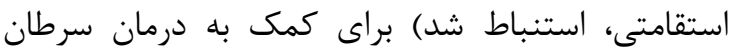

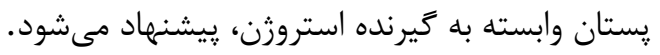

\section{تقدير و تشكر}

يرزوهش حاضر مستخرج از پإيان نامه كارشناسى ارشد

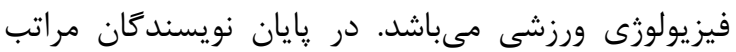
سياس از تمام آزمودنىهايى كه ما را در انجام اين يزوهش نيان

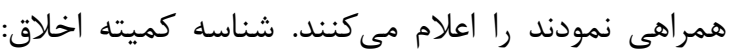
IR.SSRI.REC.1395.129 مىباشد.
هوازى تا حدودى به علت افت عوامل التهابى مانند IL-6 و افزايش let-7a است. در همين راستا يافتههاى

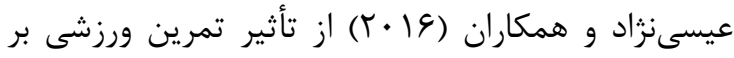
كاهش رشد تومور در سرطانهاى مدل موشى حمايت

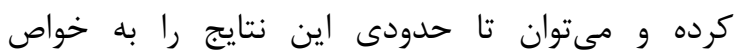

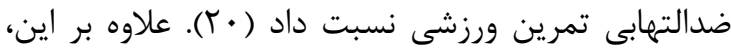

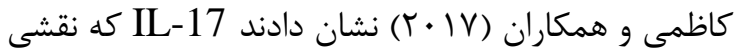
مؤثرى در متاستاز و ركزايى داد در نتيجه ورزش به موازات كاهش حجم تومور است، كاهش مى ديابد. همجنين

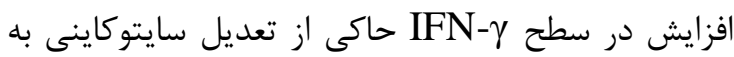

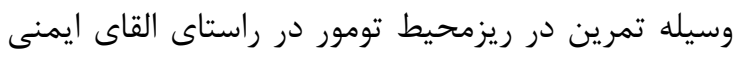

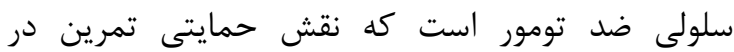
تحريك ايمنى ضد تومور را، نشان مىدهند (• آس). با توجه به اثر افزايشى تمرين ورزشى هوازى بر بيان اثر كاهشى بر بيان ERa و كاهش سطوح استراديول يلاسما در موشهاى مبتلا به سرطان يستان، تمرين هوازى، اين حلقه تنظيمى را به سمت كاهش تكثير سلولى بلى داني ييش مىبرد و مىتواند به عنوان سازوكار نوين در بيان اثرات مثبت و كمك درمانى فعاليت ورزشى بر سرطان

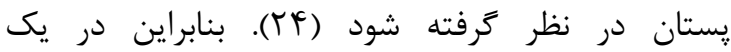
جمعبندى و با توجه به نتايج يزوهش حاضر مئتونان نتيجه كرفت تمرينات استقامتى نقش مؤثرى در بازدارى از رشد تومور در سرطانهاى وابسته به استروزن دارد.

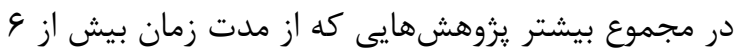

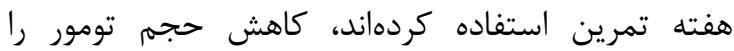
كزارش كردهاند. به نظر مىرسد فعاليت منظمه ورزشى از

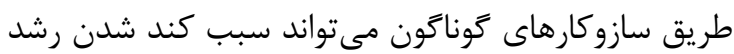

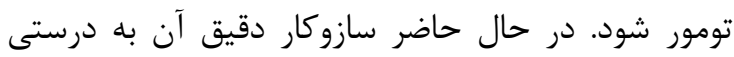
مشخص نيست اما با توجه به تحقيقات ذكر شده به نظر اندر

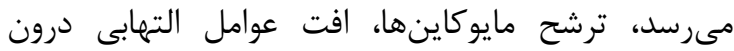

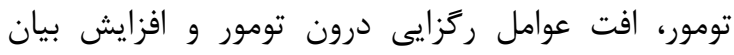

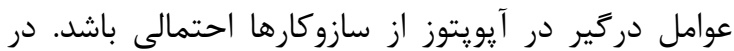
يزوهش حاضر نيز افزايش سطوح كاسيازهاى ب و و 9 احتمالاً سبب كاهش رشد رجم رجم تومور شده است. احتمالاً يكى ديكر از اثرات مثبت تمرينات استقامتى علاوه بر ترداه اثرات مولكولى ذكر شده بركاسياز ب و 9، جلوكيرى از آتروفى عضلانى مرتبط با سرطان است. تحقيقات ديگر نيز

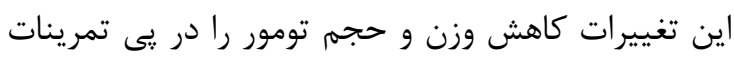

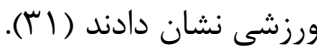




$$
\begin{aligned}
& \text { نويسندكان اعلام مىدارند كه هينج تعارض منافعى در } \\
& \text { ئزوهش حاضر وجود ندارد. }
\end{aligned}
$$

\section{References}

1. Jehn CF, Flath B, Strux A, Krebs M, Possinger $\mathrm{K}$, Pezzutto A, Lüftner $\mathrm{D}$. Influence of age, performance status, cancer activity, and IL-6 on anxiety and depression in patients with metastatic breast cancer. Breast Cancer Res Treat 2012; 136(3):789-94.

2. Norii Daloii MR, Tabarestani S. Molecular Genetics. Diagnosis and treatment of breast cancer, review. Journal of Sabzevar University of Medical Sciences 2010; 17(2):74-87.

3. Snoussi K, Mahfoudh W, Bouaouina N, Ahmed SB, Helal AN, Chouchane L. Genetic variation in IL-8 associated with increased risk and poor prognosis of breast carcinoma. Hum Immunol 2006; 67(12):13-21.

4. Chien SY1, Wu YC, Chung JG, Yang JS, Lu HF, Tsou MF, et al. Quercetininduced apoptosis acts through mitochondrial- and caspase-3-dependent pathways in human breast cancer MDAMB-231 cells. Hum Exp Toxicol 2009; 28(8): 493-503.

5. Creagh EM. Caspase crosstalk: integration of apoptotic and innate immune signalling pathways. Trends Immunol 2014; 35(12): 631-40.

6. Devarajan E, Sahin AA, Chen JS, Krishnamurthy RR, Aggarwal N, Brun AM, et al. Down-regulation of caspase 3 in breast cancer: a possible mechanism for chemoresistance. Oncogene 2002; 21(57): 8843-51.

7. Zhong N, Chen $\mathrm{H}$, Zhao Q, Wang $\mathrm{H}$, Yu $\mathrm{X}$, Eaves AM, et al. Effects of griseofulvin on apoptosis through caspase-3- and caspase-9-dependent pathways in K562 leukemia cells: An in vitro study. Curr Ther Res Clin Exp 2010; 71(16): 384-97.

8. Rodríguez-Berriguete G, Galvis L, Fraile B, de Bethencourt FR, Martínez-Onsurbe

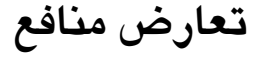

P, Olmedilla G, Paniagua $\mathrm{R}$, et al. Immunoreactivity to caspase-3, caspase-7, caspase-8, and caspase- 9 forms is frequently lost in human prostate tumors. Hum Pathol 2012; 43(2): 229-37.

9. Harada H, Hiraoka M, Kizaka-Kondoh S. Antitumor effect of TAT-oxygendependent degradation-caspase-3 fusion protein specifically stabilized and activated in hypoxic tumor cells. Cancer Res 2002; 62(7): 2013-8.

10. Yang S, Zhou Q, Yang XC. Aspase-3 status is a determinant of the differential responses to genistein between MDA-MB231 and MCF-7 breast cancer cells. Biochim Biophys Acta 2007; 1773(6): 903-11.

11. Li Y, Liu J, Liu X, Xing K, Wang Y, Li F, Yao L. Resveratrol-induced cell inhibition of growth and apoptosis in MCF7 human breast cancer cells are associated with modulation of phosphorylated Akt and caspase-9. Appl Biochem Biotechnol 2006; 135(3): 181-92.

12. Ho YT, Lu CC, Yang JS, Chiang JH, Li TC, Ip SW, Hsia TC, et al. Berberine induced apoptosis via promoting the expression of caspase-8, -9 and -3 , apoptosis-inducing factor and endonuclease $\mathrm{G}$ in SCC-4 human tongue squamous carcinoma cancer cells. Anticancer Res 2009; 29(10): 4063-70.

13. Moshtaghi Fateme, Esmaeilzadeh Bahabadi Sedighe, Mazaheri Mahta, Najafi Shahla, Dahmardeh Ghalenoo Fateme. Increasing caspase 3 gene expression in mcf7 breast cancer cell line by nigella sativa hydro alcoholic extract. J Shahid Sadoughi Univ Med Sci 2016; 24: 1-11.

14. Morales-Cano D, Calviño E, Rubio V, Herráez A, Sancho P, Tejedor MC, Diez JC. Apoptosis induced by paclitaxel via $\mathrm{Bcl}-2$, Bax and caspases 3 and 9 activation in NB4 human leukaemia 
cells is not modulated by ERK inhibition. Exp Toxicol Pathol 2013; 65: 1101-8.

15. Shalamzari SA, Hamid Agha-Alinejad, Shaban Alizadeh, Shirin Shahbazi, Zahra Kashani Khatib, AbdolReza Kazemi, et al. The effect of exercise training on the level of tissue IL-6 and vascular endothelial growth factor in breast cancer bearing mice. Iran J Basic Med Sci 2014; 17: 23158.

16. Essmann F, Engels IH, Totzke G, Schulze- Osthoff K, Jänicke RU. Apoptosis resistance of MCF-7 breast carcinoma cells to ionizing radiation is independent of p53 and cell cycle control but caused by the lack of caspase- 3 and a caffeine-inhibitable event. Cancer Res 2004; 64: 7065-72.

17. Lee JS, Jung WK, Jeong MH, Yoon TR, Kim HK. Sanguinarine induces apoptosis of HT-29 human colon cancer cells via the regulation of $\mathrm{Bax} / \mathrm{Bcl}-2$ ratio and caspase-9-dependent pathway. Int $\mathrm{J}$ Toxicol 2012; 31: 70-7. O'Donovan $\mathrm{N}$ O'Donovan N1, Crown J, Stunell H, Hill $\mathrm{AD}$, McDermott $\mathrm{E}, \mathrm{O}$ Higgins $\mathrm{N}$, et al. Caspase 3 in breast cancer. Clin Cancer Res 2003; 9: 738-42.

18. Afshar Jafari,1 Hassan Pourrazi,1, Saeid Nikookheslat, and Behzad Baradaran. Effect of Exercise Training on Bcl-2 and Bax Gene Expression in the Rat Heart. Gene Cell Tissue. 2015; 1;182:258-66.

19. Sun, Chen XY, Liu J, Cheng XX, Wang XW, Kong QY, et al. Differential caspase3 expression in noncancerous, premalignant and cancer tissues of stomach and its clinical implication. Cancer Detect Prev 2006; 30: 168-73.

20. Kim PK, Armstrong M, Liu Y, Yan P, Bucher B, Zuckerbraun BS, et al. IRF-1 expression induces apoptosis and inhibits tumor growth in mouse mammary cancer cells in vitro and in vivo. Oncogene 2004; 23: 1125-35.

21. Khori V, Shalamzari SA, Isanejad A, Alizadeh AM, Alizadeh S, Khodayari S, et al. Effects of exercise training together with tamoxifen in reducing mammary tumor burden in mice: Possible underlying pathway of miR-21. European journal of pharmacology 2015; 765: 179-87.
22. Isanejad A1, Alizadeh AM2, Amani Shalamzari S3, Khodayari H4, Khodayari S4, Khori V5, Khojastehnjad N6. MicroRNA-206, let-7a and microRNA-21 pathways involved in the anti-angiogenesis effects of the interval exercise training and hormone therapy in breast cancer. Life Sci 2016; 15: 30-40.

23. Mirakhori Z, Kordi M, Alizadeh SH, Gaieni AA, et al. The investigation of the Preventive and Therapeutic Therapy Assistance on the Growth Rate of the Tumor, E2 and expression of 206-miR and $\mathrm{ER} \alpha$ tumor tissue of breast cancer. Journal of Applied exercise Physiology 2016; 11 : 87-98.

24. Zielinski MR, Muenchow M, Wallig MA, Horn PL, Woods JA. Exercise delays allogeneic tumor growth and reduces intratumoral inflammation and vascularization. Journal of Applied Physiology 2004; 96: 2249-56.

25. Murphy EA, Davis JM, Barrilleaux T, McClellan J, Steiner J, Carmichael M, et al. Benefits of exercise training on breast cancer progression and inflammation in $\mathrm{C} 3$ (1) SV40Tag mice. Cytokine 2011; 55: 274-9.

26. Jones LW, Viglianti BL, Tashjian JA, Kothadia SM, Keir ST, Freedland SJ, et al. Effect of aerobic exercise on tumor physiology in an animal model of human breast cancer. Journal of Applied Physiology 2010; 108: 343-8.

27. Amani-Shalamzari S, Aghaalinejad H, Alizadeh SH, Kazemi AR, Saei MA, Minayi N, et al. The effect of endurance training on the level of tissue IL-6 and VEGF in mice with breast cancer. $J$ Shahrekord Univ Med Sci 2014; 16: 10-21.

28. Salmasifard Amir Hesam, Hamid Agha Ali Nejad, Alireza Rahimi. Effect of Endurance Training on Tumor Tissue IL-2 Cytokine Levels in Breast Cancer Bearing Mice. IJBD 1394; 8: 34-41.

29. Kazemi AR, Agha Alinejad H, Rasul Eslami, Ehsan P, Baghaie R, Dabaghzadeh $\mathrm{R}$, Ghanbarzadeh $\mathrm{M}$. Investigating the Effect of Endurance Training on Tumor Level of IL-8 and Serum Level of IL-17 in Female Mice with Breast Cancer. Journal 
of Fasa University of Medical Sciences 2015; 5:347-55.

30. Pettan-Brewer C, Goh J, Ladiges WC.An immunohistochemical approach for monitoring effects of exercise on tumor stromal cells in an old mice. Pathobiol Aging Age Relat Dis. 2014 Aug $11 ; 4$. 